\title{
The Fine Structure of Fusiformis nodosus with Special Reference to the Location of Antigens Associated with Immunogenicity
}

\author{
P. D. WALKER, J. SHORT, R. O. THOMSON AND D. S. ROBERTS \\ Department of Bacteriology, Wellcome Research Laboratories, \\ Langley Court, Beckenham, Kent
}

(Received 29 December 1972)

SUMMARY

In an attempt to locate the antigens associated with protection against foot-rot the fine structure of Fusiformis nodosus and the interaction between the organism and specific antiserum obtained from vaccinated animals were studied.

The high titres of circulating agglutinin associated with immunity were shown to be due to the interaction between antibodies and pili. These observations are discussed in relation to the structure and pathogenicity of other Gram-negative organisms.

\section{INTRODUCTION}

Ovine foot-rot is a highly contagious disease characterized by inflammation of the interdigital skin and hoof matrix leading to separation of the hoof from the soft tissues. The disease is due to a mixed bacterial infection of the uncornified epidermis by Fusiformis nodosus and F. necrophorus (Beveridge, 1941; Egerton, Roberts \& Parsonson, 1969; Roberts \& Egerton, 1969). Prolonged wet conditions are necessary to allow bacterial invasion of the skin; the spread of foot-rot ceases when the environment becomes dry.

Foot-rot is a chronic disease and repeated infections confer little, if any, natural immunity. Successful protection of sheep against artificial challenge with foot-rot following subcutaneous or intramuscular inoculation of a vaccine consisting of a formolized suspension of Fusiformis nodosus emulsified in an oily adjuvant was reported by Egerton \& Roberts (I97I). Similar vaccines were also effective under conditions of natural challenge (Egerton \& Burrell, I970; Skerman, I97I). Good field protection has also been reported for a vaccine with potash alum as adjuvant (Roberts, Foster, Kerry \& Calder, 1972).

In an attempt to locate the antigens associated with the stimulation of immunity and to elucidate the effects of antibody on the bacterial cells the ultrastructure of Fusidormis nodosus and the interaction between $F$. nodosus cells and specific antiserum obtained from vaccinated animals were studied.

\section{METHODS}

Organism. Fusiformis nodosus cultures, Wellcome Research Laboratories collection 6475 and 6476 were used.

Growth. Portions $(450 \mathrm{ml}$ ) of the culture medium consisting of $3 \%$ bacteriological peptone (Wellcome Reagents Ltd) $+0.5 \%$ yeast extract (Difco) were inoculated with $50 \mathrm{ml}$ of an overnight broth culture. Samples were removed at appropriate intervals, measured for turbidity in a nephelometer and examined with the electron microscope. 
Ferritin labelling of antibody. Antisera obtained from sheep vaccinated as described by Roberts et al. (I972), were conjugated with ferritin using the method of Singer \& Schick (I961).

Antigen antibody reactions. A formolized suspension of Fusiformis nodosus prepared by treating a young $12 \mathrm{~h}$ culture with $0.6 \%$ formalin at $37^{\circ} \mathrm{C}$ for $48 \mathrm{~h}$ was reacted with antibody or ferritin-labelled antibody according to the method of Walker, Baillie, Thomson \& Batty (1966). The reaction mixture was examined with the electron microscope as described below. Controls of formolized organisms shaken with normal sheep serum were also included.

\section{Electron microscopy}

Negative staining. A sample was centrifuged, the supernatant removed and the deposit resuspended in distilled water. One volume of the suspension was immediately mixed with an equal volume of $3 \%$ phosphotungstic acid, $\mathrm{pH} 7 \cdot 2$, and a drop of this mixture placed on a 400-mesh carbon-coated formvar-covered copper grid. The excess fluid was removed with a filter paper, the grid allowed to dry and examined in a Philips EM 200 microscope at $60 \mathrm{kV}$.

Sections. A further sample was fixed according to the method of Kellenberger, Ryter \& Sechaud (1958) and embedded in maraglas (Freeman \& Spurlock, I962). Sections were cut on an L.K.B. Ultratome and collected on 200 mesh formvar-coated grids. The sections were stained with lead citrate (Reynolds, 1963) and examined as described above.

Antigen antibody reactions. The antigen antibody reaction mixture prepared as described above was centrifuged, the agglutinated organisms resuspended in a small amount of distilled water and immediately examined by negative staining with phosphotungstic acid as described above.

Purification of pili. Purified pili were prepared according to the method of Brinton (1965). Organisms in the logarithmic phase of growth were centrifuged, resuspended in distilled water and agitated for $2 \mathrm{~min}$ in a high-speed mixer. After separation of the cells by lowspeed centrifugation the supernatant was adjusted to $\mathrm{pH} 4.0$ when isoelectric precipitation of the pili occurred. The aggregated pili were collected by centrifugation and resuspended in distilled water. After neutralization the preparation was made $0 \cdot \mathrm{I} \mathrm{M}$ with $\mathrm{MgCl}_{2}$ in the cold, when specific aggregation of the pili again occurred. Two more cycles of magnesium precipitation yielded a pure pili suspension when examined in the electron microscope.

Preparation of pili antisera. A suspension of pili at a protein concentration of approximately $0 . \mathrm{I} \mathrm{mg} / \mathrm{ml}$ was absorbed on to $2 \%$ potash alum at $\mathrm{pH} 6.0$. Rabbits and sheep in groups of five were immunized with $2 \times 2 \mathrm{ml}$ doses of the vaccine subcutaneously with an interval of 6 weeks between injections. Antisera were collected I4 days after the second injection and tested by agglutination with a formolized suspension of young cells and a similar suspension killed by heating at $100^{\circ} \mathrm{C}$ for $\mathrm{I} \mathrm{h}$.

\section{Growth}

\section{RESULTS}

Nephelometer readings showed a classical growth curve consisting of lag phase, logarithmic phase, stationary phase and phase of decline. The logarithmic phase lasted approximately $12 \mathrm{~h}$ and the maximum number of organisms was approximately $2 \times 10^{9} / \mathrm{ml}$. 


\section{Electron microscopy}

Negative staining. Cultures in the logarithmic phase of growth were heavily piliated (Fig. I). The pili which in many cases emerged in clusters from one end of the cell (Fig. 2) were approximately $6 \mathrm{~nm}$ in diam. and up to $5 \mu \mathrm{m}$ in length. During the stationary phase the numbers of pili rapidly decreased and lysis of the cell, as evidenced by release of lipopolysaccharide blebs (Fig. 3), was observed. During the phase of decline there was a complete absence of pili and extensive lysis of the cell. In some preparations of purified pili structures resembling the incomplete phage described by Kellenberger \& Boy de la Tour (1965) were seen (Fig. 9).

Sections. The structure of young vegetative cells of Fusiformis nodosus is shown in Fig. 4. The structure is typical of Gram-negative bacteria, the wall being a complex structure in which a thin strand of mucopeptide is sandwiched between the cytoplasmic membrane and the outer layer which also has a membrane-like structure. Extensive lysis was seen in sections from organisms in the stationary phase (Fig. 5).

Antigen antibody reactions. Suspensions of cells treated with antibody alone and antibody labelled with ferritin showed specific agglutination of the pili (Fig. 6, 7). In preparations stained with ferritin-labelled antibody ferritin particles were specifically located along the pili (Fig. 8). Antibody molecules could be seen linking the pili together in preparations treated with antibody alone (Fig. $9 b$ ). No reaction was seen with normal sheep serum.

\section{Agglutination tests}

After two injections of the vaccine the sera of rabbits and sheep had mean agglutination titres against formolized cells of $I$ in 20000 and $I$ in 26000 respectively. Titres with heatkilled cells were less than I in 40.

Typical agglutination titres against formolized cells obtained with routine commercial whole culture vaccine (Wellcome Foot-Rot Vaccine A.T.F.C.) in rabbits and sheep were $I$ in $I 000$ and $I$ in $I 6000$ respectively.

\section{DISCUSSION}

In the present study three facts have been clearly established: (i) cultures of Fusiformis nodosus are heavily piliated during the logarithmic phase of growth, the numbers of pili rapidly declining after the termination of this phase; (ii) the pili are antigenic; and (iii) agglutination of the organism with serum from vaccinated animals is due to the reaction of pili with antibody. Egerton (1973) in an antigenic analysis of $F$. nodosus refers to surface and somatic antigens. His surface or ' $\mathrm{K}$ ' antigens are almost certainly the pili reported in the present communication. Furthermore, vaccination with a purified preparation of pili elicits an agglutinin response identical to that given by injection of the commercial vaccine prepared from formolized whole cultures. Egerton \& Roberts (I97I) have previously shown that protection against foot-rot is associated with high agglutination titres.

The description of pili and the characterization of their physical and chemical properties, particularly their adhesive properties, is well documented (Anderson, 1949; Houwink \& van Iterson, 1950; Brinton, Buzzell \& Lauffer, I954; Duguid, Smith, Dempster \& Edmunds 1955; Brinton, 1959, 1965). However, little attention has been paid to their possible ancillary pathogenic role. They occur very widely among Gram-negative bacteria, particularly on strains freshly isolated from natural sources. Duguid (1968) has suggested that they are helpful for the maintenance of commensalism but that fimbriation does not markedly influence the pathogenicity of the organism. 


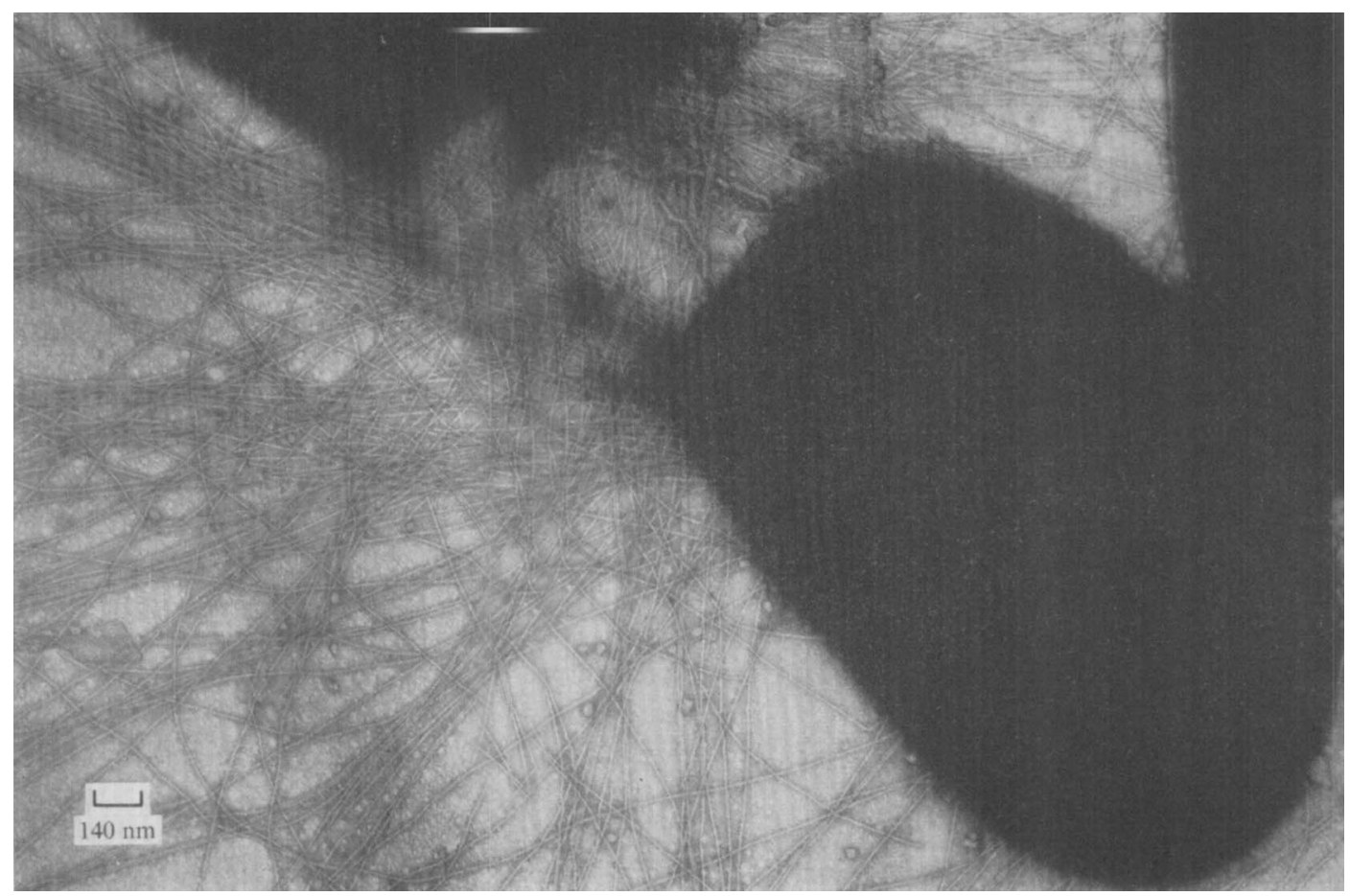

Fig. I. Negatively stained preparation of young io h broth culture of Fusiformis nodosus showing large numbers of pili present on the cells.

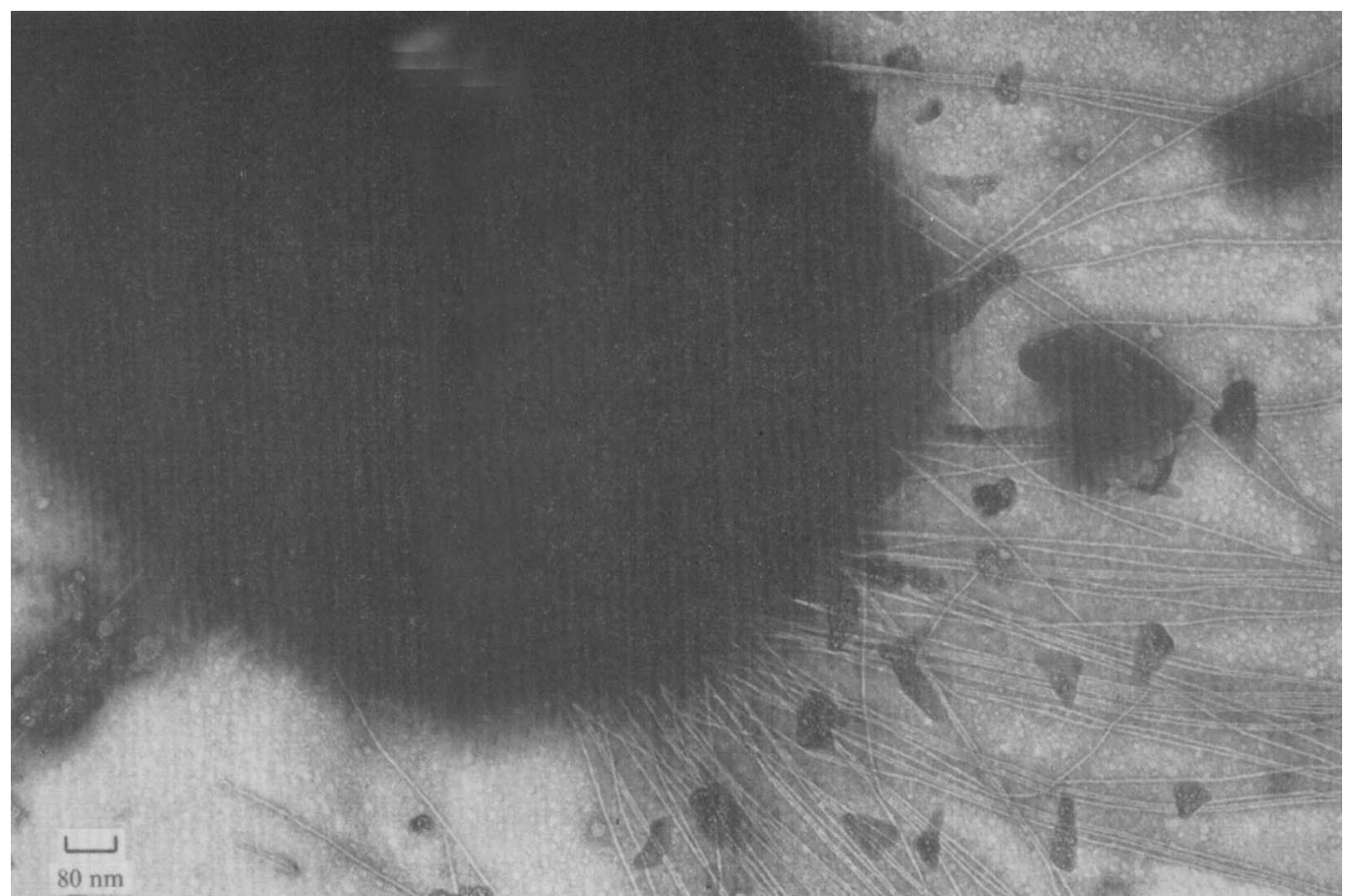

Fig. 2. Similar preparation to Fig. I showing characteristic emergence of pili from the pole of the cell. 


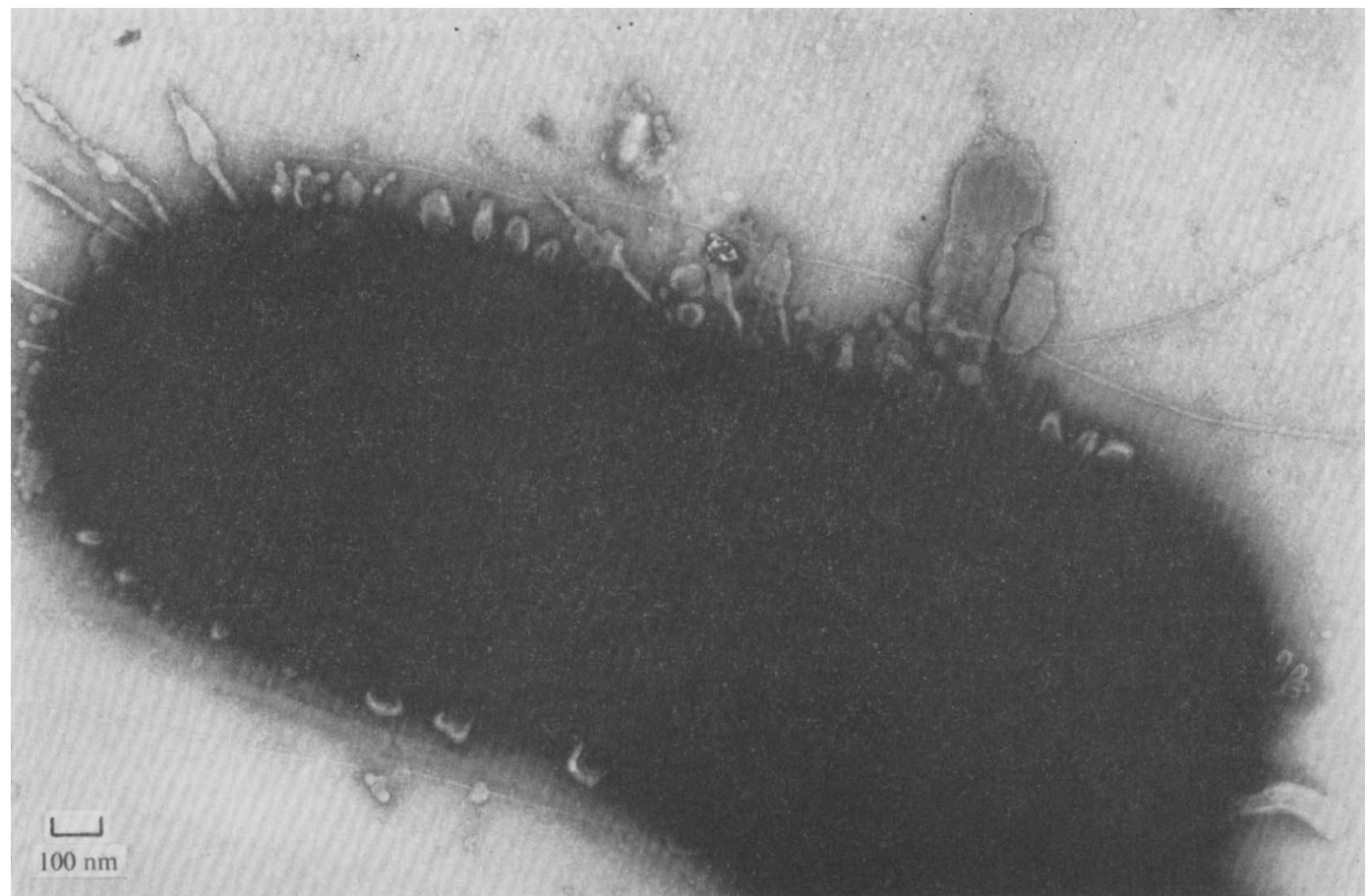

Fig. 3. Negatively stained preparation of $24 \mathrm{~h}$ broth culture of $F$. nodosus. Small numbers of pili are present in the background and the surface of the cell is characterized by the presence of blebs of lysed material.

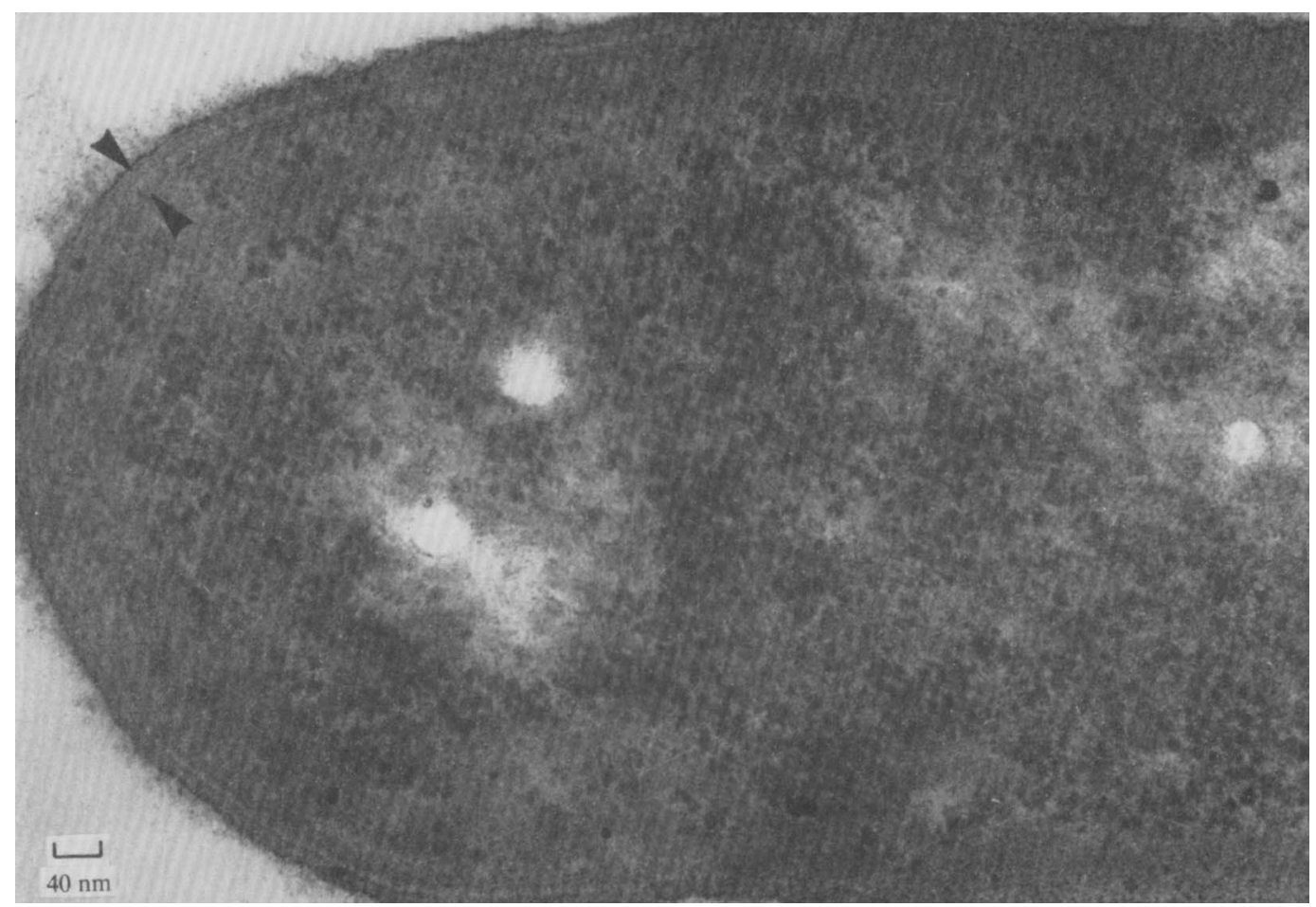

Fig. 4. Ultrathin section of young $10 \mathrm{~h}$ broth culture of $F$. nodosus showing characteristic structure of Gram-negative bacteria. 


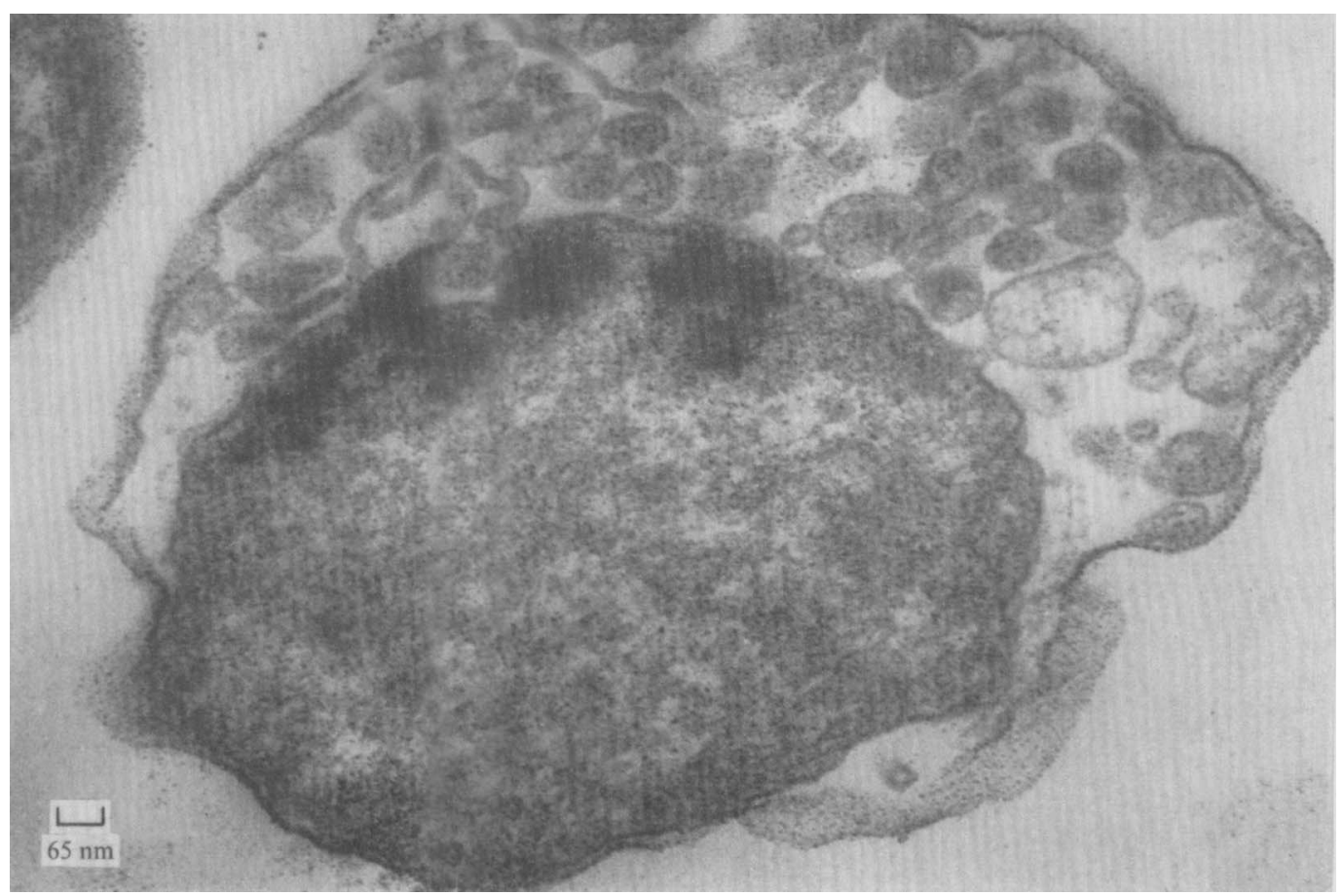

Fig. 5. Ultrathin section of $24 \mathrm{~h}$ broth culture of $F$. nodosus. Note extensive lysis of the cell.

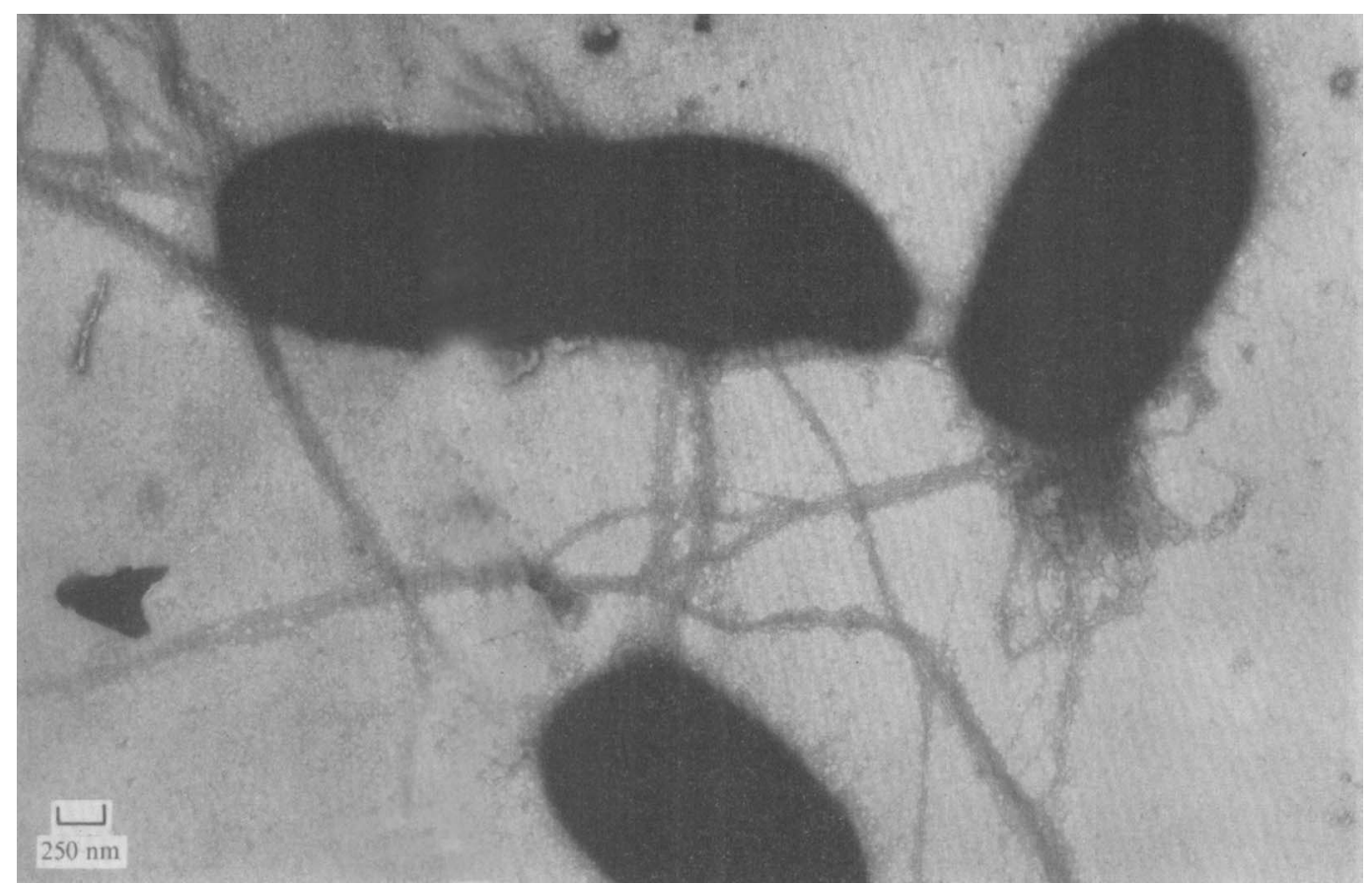

Fig. 6. Negatively stained preparation of young $10 \mathrm{~h}$ broth culture of $F$. nodosus after treatment with antiserum obtained from vaccinated animals. Note specific agglutination of the organism by aggregated pili. 


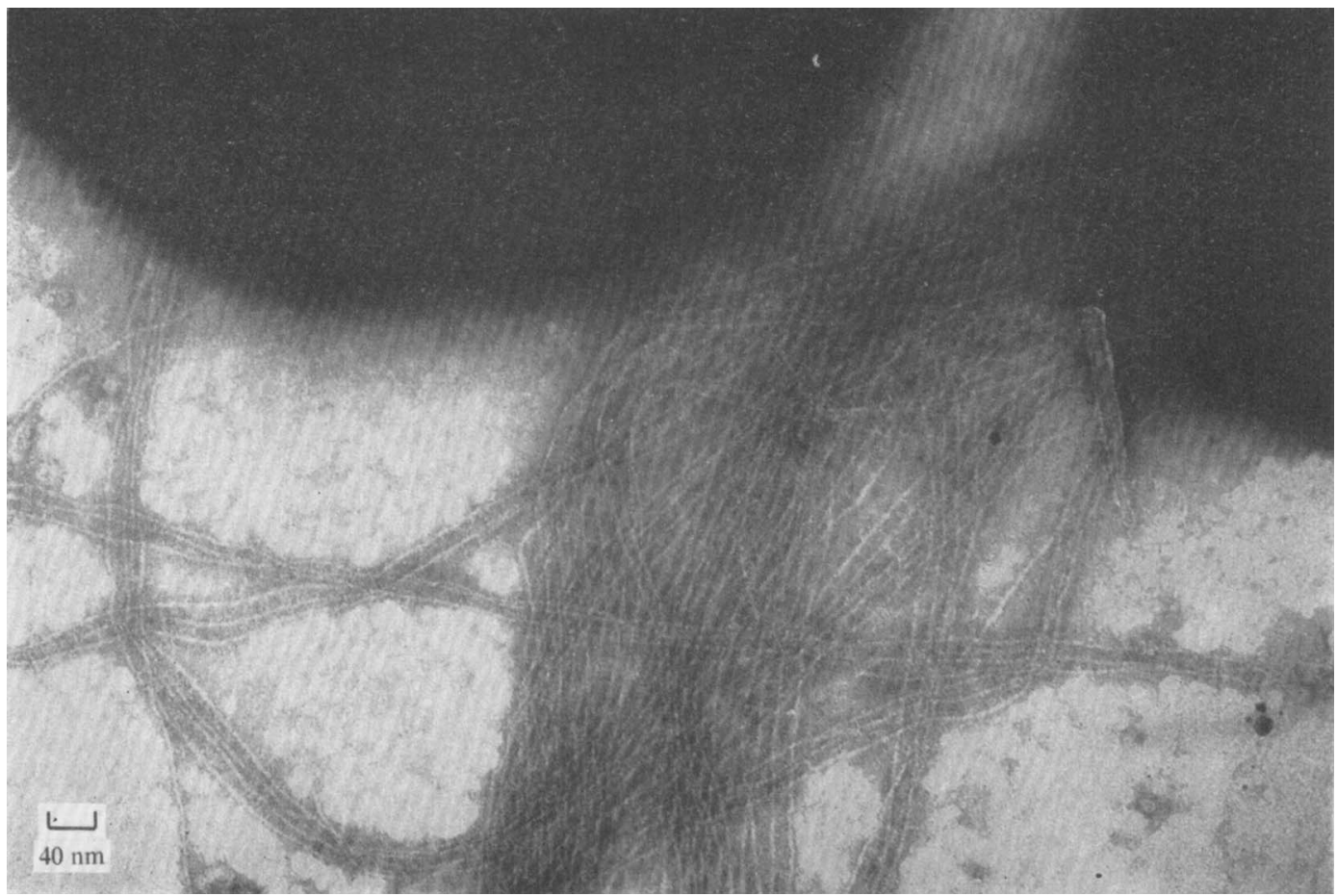

Fig. 7. Negatively stained preparation of young to h broth culture of $F$. nodosus after treatment with antiserum obtained from vaccinated animals. Note specific agglutination of the pili.

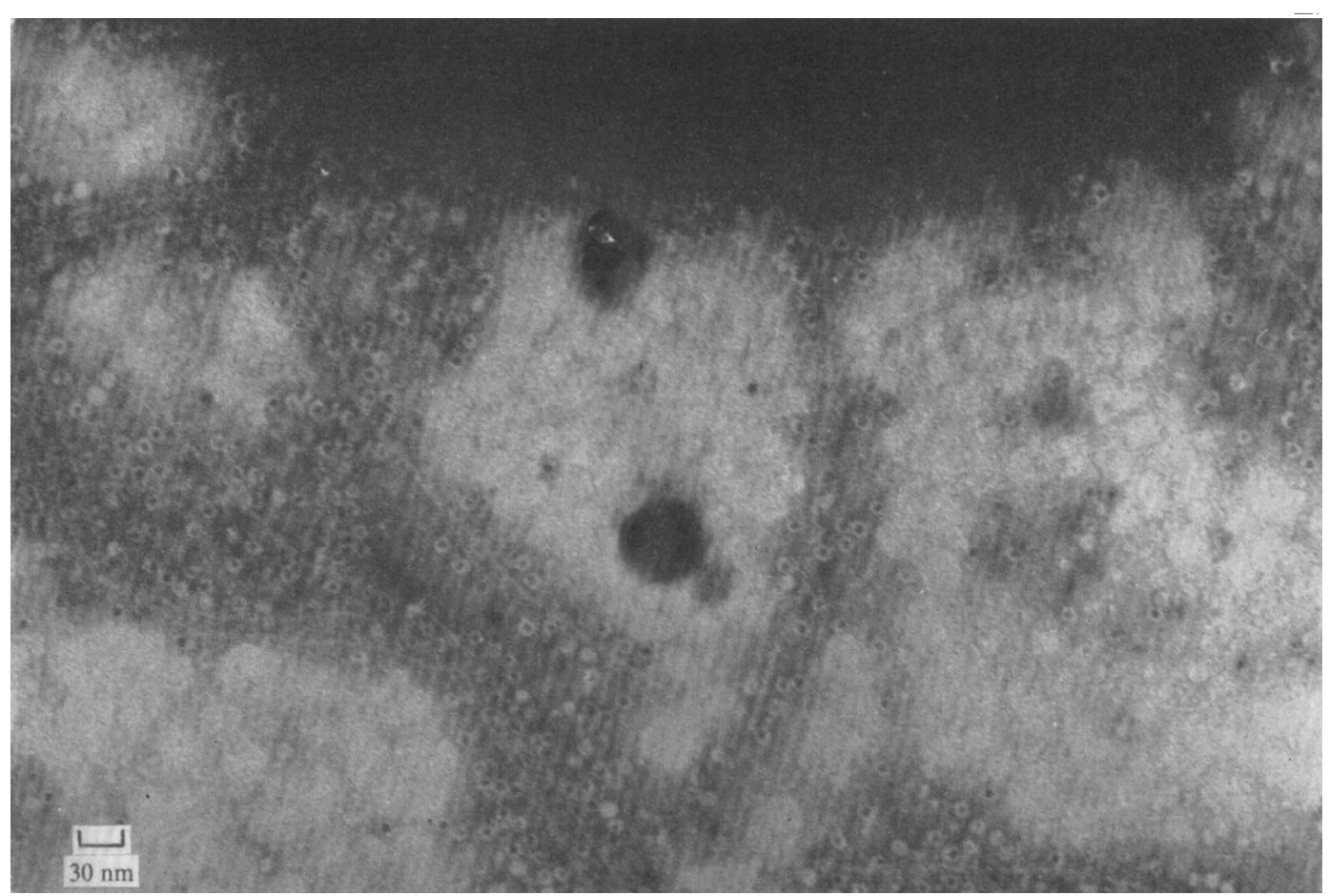

Fig. 8. Negatively stained preparation of young $10 \mathrm{~h}$ broth culture of $F$. nodosus stained with ferritinlabelled antibody. Note specific labelling of the pili with ferritin particles. 


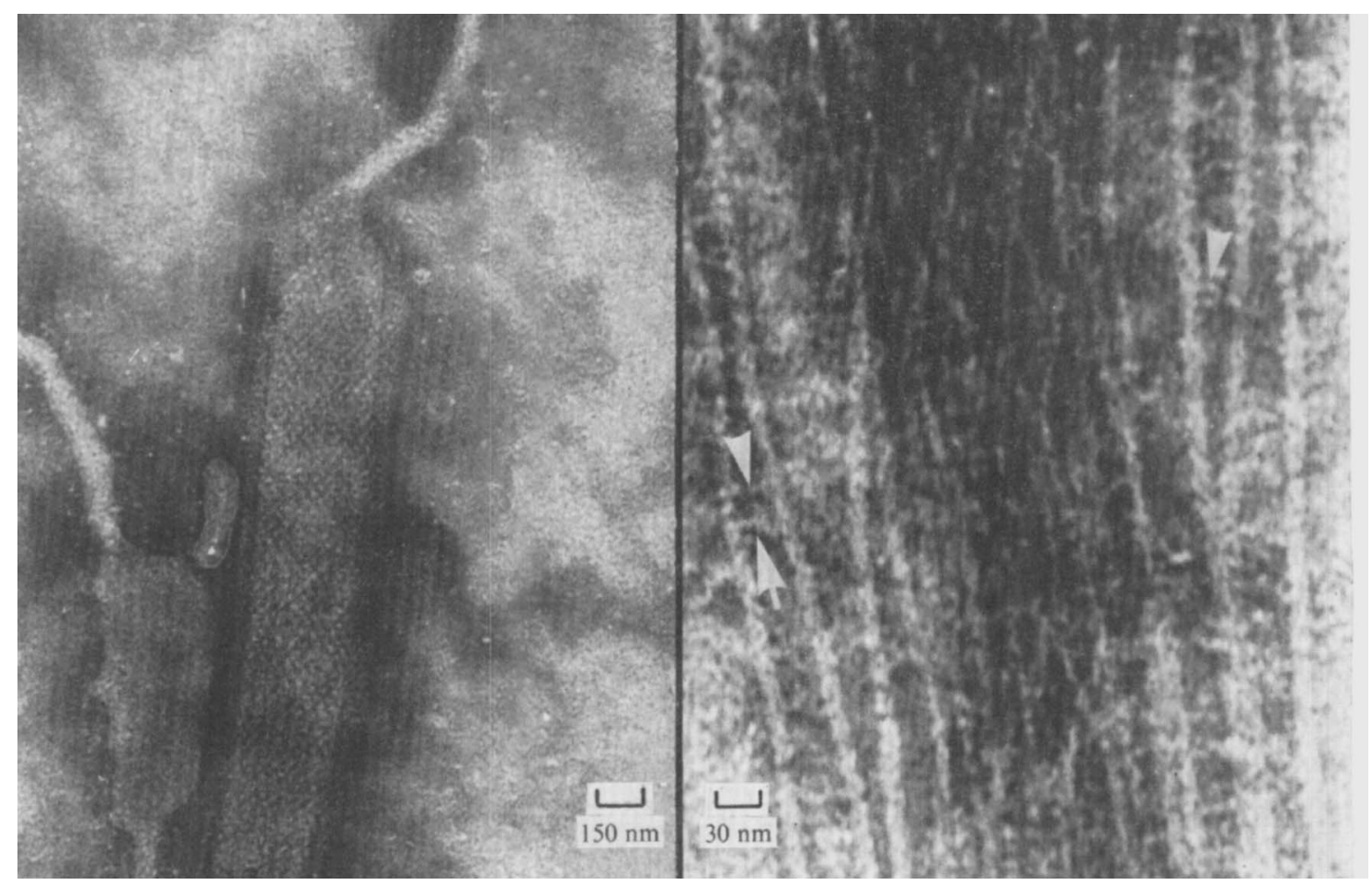

Fig. 9 (a). Negatively stained preparation of purified pili showing a hexagonally patterned tubular structure.

Fig. $9(b)$. Negatively stained preparation of purified pili after treatment with antiserum obtained from vaccinated animals. Antibody molecules (arrows) can be seen linking the pili together.

More recently, the virulence of gonococci has been shown to be genetically linked to clonal variation which is associated with colonial morphology and the presence or absence of pili (Kellogg et al. 1963, I968; Swanson, Kraus \& Gotschlich, 1971). Kellogg et al. (1963) defined four colony types of Neissesie gonorrheae. Types I and 2 grew as small colonies on agar; types 3 and 4 were considerably larger. Gonococci freshly isolated from patients with gonorrhea were invariably of colony types $I$ and 2 but these rapidly reverted to types 3 and 4 on unselected transfer in the laboratory. In experiments on volunteers it was shown that clonal variation and pathogenicity could be maintained through some 700 passages in vitro providing colony types I and 2 were continually selected (Kellogg et al. I968). It has been established that types $I$ and 2 are piliated, whereas types 3 and 4 are characterized by the absence of pili (Swanson et al. 1971). Although the interpretation of Kellogg's results has recently been challenged (Ward, Watt \& Glynn, 1970; Watt, Glynn \& Ward, 1972), the relationship between piliation, colonial morphology and virulence has been clearly established.

A relationship between piliation and colonial morphology has also been described in Escherichia coli (Brinton, 1965) and Moraxella nonliquefaciens (Bovre, Bergan \& Froholm, 1970), an organism capable of causing eye infections. The K. 88 antigen of $E$. coli was first described by Ørskov, Ørskov, Sojka \& Leach (196I) and shown to be associated with most of the strains found in diseases of swine. It has been suggested that the presence of $\mathrm{K} .88$ 
antigen may have some bearing on the pathogenicity of $E$. coli in piglets. The structure of the K. 88 antigen was described by Stirm, Ørskov, Ørskov \& Birch-Andersen (1967) who demonstrated that the antigen had the appearance of fine filaments more flexible than fimbriae. Morphological and fluorescent labelled antibody studies have shown that the K. 88 antigen is very important in adherence of the organism to the villi in the intestine and this is presumably the first stage in the pathogenicity of $E$. coli infection (Arbuckle, I97I ; Jones \& Rutter, 1972).

No other aspect of the structure of Fusiformus nodosus has thrown light on the nature of the protective antibodies. The structure of the organism is similar to that of other Gramnegative bacteria and the structure and chemical composition of the cell envelope of the organism is consistent with that described for other Gram-negative bacteria (Schnaitman, I97I; de Petris, 1967). The observation of incomplete phage in some of the purified pili preparations probably indicates that these might be responsible for the rapid lysis of the organism at the end of the logarithmic phase of growth. Whether the presence of phage is associated with pathogenicity, as has been shown in the production of bacterial toxins (e.g. Matsuda \& Barksdale, 1967), remains to be investigated.

Our most significant finding is the location of the agglutinogen of Fusiformis nodosus on its pili especially as there is a definite correlation between the agglutination titres found in vaccinated animals and protection against ovine foot-rot. The observation that the protective effect of vaccination is manifested only after infection, when $F$. nodosus is already embedded in epidermal tissue (Egerton \& Roberts, 197I) suggests that antipili antibodies do not affect the initial attachment to epidermal cells but that such antibodies might act to prevent the spread of organisms through the epidermis as it comes into contact with antibody. Presumably due to the superficial nature of the disease sufficient antigen does not reach the antibody-forming cells to provoke natural immunity. On the other hand, the production of high titres of antipili antibodies in the blood stream by artificial immunisation with a vaccine prepared from formolized young cultures of $F$. nodosus probably prevents the spread of the disease and allows the elimination of the organism by bactericidal antibodies also present in the serum of normal and immunized animals (Egerton \& Merritt, 1970). Failure to produce adequate agglutination titres and protection in animals vaccinated with vaccines prepared from old broth cultures can be attributed to the previously described loss of pili under such conditions.

While the role of circulating antibody has been emphasized in the above discussion, possible alternative mechanisms involving cellular factors which are important in mycobacteria and other Gram-negative infections may be involved. In this type of immunity, sensitization of lymphocytic cells and potentiation of the protective role of phagocytic cells appear to be more important than the role of circulating antibody (Collins, I971). However, at the present time there is no evidence that this type of mechanism is important in protection against foot-rot.

Field trials comparing commercial whole cell vaccine and vaccine made from purified pili are in progress and should further contribute to the elucidation of the role of pili as protective antigens. A similar study aimed at evaluating the role of gonococcal pili as protective antigens may lead to the development of a successful vaccine against this organism.

We should like to acknowledge the invaluable technical assistance of $\mathrm{Mr}$ P. Hine during the course of this work. 
Note added at proof. Since this paper was accepted for publication a short article giving some preliminary observations on the structure of Fusiformis nodosus has appeared ('An Electron Microscopic Study of Fusiformis nodosus' by D. J. Stewart (1973), Research in Veterinary Science 14, I32-I34). This author notes that cells grown on agar possess numerous appendages, whereas cells grown in broth have very few. It is clear from the above observations that cells grown in broth are equally heavily piliated providing the correct growth stage is selected. He further speculates on the possible role of these structures as protective antigens but presents no direct evidence such as is presented in this paper in support of this.

\section{REFERENCES}

ANDERSON, T. F. (1949). On the mechanism of adsorption of bacteriophages to host cells. In The Nature of the Bacterial Surface, pp. 79-95. Edited by A. A. Miles and N. W. Pirie. Cambridge: Cambridge University Press.

ARBUCKLE, J. B. R. (197I). Enteropathogenic Escherichia coli on the intestinal mucopolysaccharide layer of pigs. Journal of Pathology 104, 93-98.

BeveridGe, W. I. B. (194I). Foot-rot in sheep: a transmissible disease due to infection with Fusiformis nodosus (n.sp.). Council for Scientific and Industrial Research, Australia, Bulletin 140, I-53.

Bovre, K., BergaN, T. \& Froholm, L. O. (1970). Electron microscopical and serological characteristics associated with colony type in Moraxella nonliquefaciens. Acta pathologica et microbiologica scandinavica 78, 765-799.

BRINTON, C. C., Jun. (I959). Non-flagellar appendages of bacteria. Nature, London 183, 782-786.

BRINTON, C. C., JUN. (1965). The structure, function, synthesis and genetic control of bacterial pili and a molecular model for DNA and RNA transport in Gram negative bacteria. Transactions of the New York Academy of Sciences 27, 1003-1054.

Brinton, C. C., Jun., Buzzell, A. \& LAUffer, M. A. (I954). Electrophoresis and phage suceptibility studies on a filament-producing variant of the $E$. coli $\mathrm{B}$ bacterium. Biochimica et biophysica acta 15 , 533-542.

Collins, F. M. (1971). Mechanisms in antimicrobial immunity. Journal of the Reticuloendothelial Society Io, 58-99.

DUGUID, J. P. (1968). The function of bacterial fimbriae. Archivum immunologiae et therapiae experimentalis I6, I73-I88.

Duguid, J. P., Smith, I. W., Dempster, G. \& Edmunds, P. N. (1955). Non-flagellar filamentous appendages ('fimbriae') and haemagglutinating activity of Bacterium coli. Journal of Pathology and Bacteriology 70 , $335-348$.

EgERTON, J. R. (1973). Surface and somatic antigens of Fusiformis nodosus. Journal of Comparative Pathology 83, I5I-159.

Egerton, J. R. \& BURrell, D. H. (I970). Prophylactic and therapeutic vaccination against ovine foot-rot. Australian Veterinary Journal 46, 517-522.

Egerton, J. R. \& Merritt, G. C. (1970). The occurrence of bactericidal antibodies against Fusiformis nodosus. Journal of Comparative Pathology 8o, 369-377.

Egerton, J. R. \& ROBERTS, D. S. (I97I). Vaccination against ovine foot-rot. Journal of Comparative Pathology 8I, 179-185.

Egerton, J. R., Roberts, D. S. \& Parsonson, I. M. (1969). The aetiology and pathogenesis of ovine foot-rot. I. A histological study of the bacterial invasion. Journal of Comparative Pathology 79, 207-217.

Freeman, J. A. \& SpurLock, B. O. (1962). A new epoxy embedment for electron microscopy. Journal of Cell Biology 13, 437-443.

Houwink, A. L. \& VAN Iterson, W. (1950). Electron microscopial observations on bacterial cytology. II. A study on flagellation. Biochimica et biophysica acta 5, 10-44.

Jones, G. W. \& RUTTER, J. M. (1972). Role of the K.88 antigen in the pathogenesis of neo-natal diarrhoea caused by Escherichia coli in piglets. Infection \& Immunity 6, 918-927.

Kellenberger, E. \& BoY DE LA Tour, E. (1965). Studies on the morphopoiesis of the head of phage T-even. II. Observations on the fine structure of polyheads. Journal of Ultrastructure Research 13, 343-358.

Kellenberger, E., Ryter, A. \& Sechaud, J. (1958). Electron microscope study of DNA containing plasms. II. Vegetative and mature phage DNA as compared with normal bacterial nucleoids in different physiological states. Journal of Biophysical and Biochemical Cytology 4, 67I-678. 
Kellogg, D. S., Jun., Cohen, I. R., Norins, L. C., Schroeter, A. L. \& Reising, G. (I968). Neisseria gonorrhoeae. II. Colonial variation and pathogenicity during 35 months in vitro. Journal of Bacteriology 96, 596-605.

Kellogg, D. S., Jun., Peacock, W. L., Jun., Deacon, W. E., Brown, L. \& Pirkle, C. I. (i963). Neisseria gonorrhoeae. I. Virulence genetically linked to clonal variation. Journal of Bacteriology 85, 1274-1279.

MATSUdA, M. \& BARKSDAle, L. (1967). System for the investigation of the bacteriophage-directed synthesis of diphtherial toxin. Journal of Bacteriology 93, 722-730.

Ørskov, I., Ørskov, F., SoJKa, W. J. \& Leach, J. M. (I96I). Simultaneous occurrence of E. coli B and L antigens in strains from diseased swine. Acta pathologica et microbiologica scandinavica 53, 404-422.

DE PETRIS, S. (1967). Ultrastructure of the cell wall of Escherichia coli and chemical nature of its constituent layers. Journal of Ultrastructure Research $\mathbf{1 9}, 45-83$.

ReYNolds, E. S. (1963). The use of lead citrate at high $\mathrm{pH}$ as an electron-opaque stain in electron microscopy. Journal of Cell Biology 17, 208-212.

Roberts, D. S. \& Egerton, J. R. (1969). The aetiology and pathogenesis of ovine foot-rot. II. The pathogenic association of Fusiformis nodosus and F. necrophorus. Journal of Comparative Pathology 79, 21 7-227.

Roberts, D. S., Foster, W. H., Kerry, J. B. \& Calder, H. A. MCC. (1972). An alum-treated vaccinéfor the control of foot-rot in sheep. The Veterinary Record 9r, 428-429.

SCHNAITMAN, C. A. (197I). Effect of ethylenediaminetetraacetic acid, triton X-I00, and lysozyme on the morphology and chemical composition of isolated cell walls of Escherichia coli. Journal of Bacteriology I08, 553-563.

Singer, S. J. \& SCHICK, A. F. (I96I). The properties of specific stains for electron microscopy prepared by the conjugation of antibody molecules with ferritin. Journal of Biophysical and Biochemical Cytology 9, 519-537.

Skerman, T. M. (197I). Vaccination against foot-rot in sheep. New Zealand Veterinary Journal I9, I 2.

Stirm, S., Ørskov, F., Ørskov, I. \& Birch-ANDERSen, A. (1967). Episome, carried surface antigen K.88 of Escherichia coli. III. Morphology. Journal of Bacteriology 93, 740-748.

Swanson, J., Kraus, S. J. \& Gotschlich, E. C. (I97I). Studies on gonococcus infection. I. Pili and zones of adhesion: their relation to gonococcal growth patterns. Journal of Experimental Medicine, 134, 886-906.

Walker, P. D., Baillie, A., Thomson, R. O. \& Batty, I. (I966). The use of ferritin labelled antibodies in the location of spore and vegetative antigens of Bacillus cereus. Journal of Applied Bacteriology 29, 5I2-518.

Ward, M. E., WATt, P. J. \& GlynN, A. A. (1970). Gonococci in urethral exudates possess a virulence factor lost on subculture. Nature, London 227, 382-384.

WATt, P. J., GLYNN, A. A. \& WARD, M. E. (1972). Maintenance of virulent gonococci in laboratory culture. Nature New Biology 236, 186. 